\title{
Physiological and transcriptional responses to inorganic nutrition in a tropical Pacific strain of Alexandrium minutum: Implications for the saxitoxin genes and toxin production
}

\author{
Kieng Soon Hii ${ }^{a}$, Po Teen Lim ${ }^{b, *}$, Nyuk Fong Kon ${ }^{a}$, Yoshinobu Takata ${ }^{c}$, Gires Usup ${ }^{d}$, \\ Chui Pin Leaw ${ }^{\mathrm{b}, *}$ \\ a Institute of Biodiversity and Environmental Conservation, Universiti Malaysia Sarawak, Kota Samarahan 94300, Sarawak, Malaysia \\ ${ }^{\mathrm{b}}$ Bachok Marine Research Station, Institute of Ocean and Earth Sciences, University of Malaya, Bachok 16310, Kelantan, Malaysia \\ ${ }^{\mathrm{c}}$ The University of Tokyo, Yayoi 1-1-1, Bunkyo-Ku, Tokyo 113-8657, Japan \\ ${ }^{\mathrm{d}}$ Faculty of Science and Technology, Universiti Kebangsaan Malaysia, 43600 Bangi, Selangor, Malaysia
}

\section{A R T I C L E I N F O}

\section{Article history:}

Received 14 January 2016

Received in revised form 12 April 2016

Accepted 12 April 2016

Available online 17 May 2016

\section{Keywords:}

Malaysia

Saxitoxin biosynthesis

sxtA

sxtG

sxtI

\begin{abstract}
A B S T R A C T
Saxitoxins (STXs) constitute a family of potent sodium channel blocking toxins, causative agents of paralytic shellfish poisoning (PSP), and are produced by several species of marine dinoflagellates and cyanobacteria. Two STX-core genes, sxtA and sxtG, have been well elucidated in Alexandrium but the expression of these genes under various nutritional modes in tropical species remains unclear. This study investigates the physiological responses of a tropical Pacific strain of Alexandrium minutum growing with nitrate or ammonium, and with various nitrogen to phosphorus $(\mathrm{N}: \mathrm{P})$ supply ratios. The transcriptional responses of the $s x t$ genes were observed. Likewise, a putative $s x t I$ encoding $O$-carbamoyltransferase (herein designated as AmsxtI) was recovered from the transcriptomic data, and its expression was investigated. The results revealed that the cellular toxin quota $\left(Q_{t}\right)$ was higher in P-depleted, nitrategrown cultures. With cultures at similar $\mathrm{N}: \mathrm{P}(<16)$, cells grown with excess ammonium showed a higher $Q_{t}$ than those grown with nitrate. sxtA1 was not expressed under any culture conditions, suggesting that this gene might not be involved in STX biosynthesis by this strain. Conversely, sxtA4 and sxtG showed positive correlations with $Q_{t}$, and were up-regulated in P-depleted, nitrate-grown cultures and with excess ambient ammonium. On the other hand, AmsxtI was expressed only when induced by P-depletion, suggesting that this gene may play an important role in P-recycling metabolism, while simultaneously enhancing toxin production.
\end{abstract}

(c) 2016 Elsevier B.V. All rights reserved.

\section{Introduction}

Saxitoxin (STX) is a tricyclic perhydropurine alkaloid that includes a family of naturally occurring neurotoxins. This alkaloid undergoes several natural substitutions at various structural positions, resulting in at least 57 known derivatives (Oshima, 1995; Onodera et al., 1997; Llewellyn et al., 2004; Lim et al., 2007a; Wiese et al., 2010). The toxin is a causative agent of paralytic shellfish poisoning (PSP) in humans, which has tremendous socioeconomic impacts in affected countries (Anderson et al., 1996; Hoagland and Scatasta, 2006; Usup et al., 2012). The PSPassociated toxins (PSTs) are produced by several species of marine dinoflagellates and prokaryotic cyanobacteria. In the marine

\footnotetext{
* Corresponding authors.

E-mail addresses: ptlim@um.edu.my (P.T. Lim), cpleaw@um.edu.my (C.P. Leaw).
}

environment, the dinoflagellates Pyrodinium bahamense, Gymnodinium catenatum, and several Alexandrium species, have the ability to produce PSTs (e.g. Oshima et al., 1993; Usup et al., 2012). The toxin profile in marine dinoflagellates is believed to be inherited in a Mendelian manner, and is thus constant among strains of the same species (Sako et al., 1992). However, the cellular toxin content is less stable phenotypically and varies among strains of the same species (Alpermann et al., 2010). The toxin production of Malaysian strains of Alexandrium minutum has been characterized in laboratory cultures (Usup et al., 2004; Lim and Ogata, 2005; Lim et al., 2006, 2010). These A. minutum strains produce mainly monosulfated GTX1/4 (>90\% mole), with small amounts of GTX2/3 and trace amounts of STX and NEO (Lim and Ogata, 2005; Lim et al., 2006, 2007b). In accordance with other studies, the relative toxin composition of Malaysian A. minutum strains is relatively stable, predominantly constituted of GTX1/4, even under different $\mathrm{N}: \mathrm{P}$ supply ratios, or under different $\mathrm{N}$-nutrition conditions (Lim et al., 